\title{
Socio- Economic and Psychological Causes of Female Prostitution in Punjab (A Case Study of District Sahiwal)
}

\author{
Haq Nawaz Anwar \\ Professor, Department of Sociology, G.C University Faisalabad, Pakistan
}

Rizwan Safdar

M. Phil Scholar, G.C University Faisalabad, Pakistan

\section{Doi:10.5901/jesr.2014.v4n3p391}

\begin{abstract}
Prostitution has been going on for many centuries. Many studies have gone on, researching and trying to understand on why women get involved with prostitution and the main effects it has on them. Present Research gives an overview of the major Socio- Economic and Psychological causes of prostitution in Punjab, Pakistan. It has also examines the social adjustment problems of prostitutes within the society and violence against female prostitutes carried out by male buyers and pimps. A sample of 10 respondents was selected for the case study from District Sahiwal, Punjab by using purposive sampling technique. Check List was designed and qualitative data was collected through face to face interview. In conclusion, the present research suggests some strategies to combat prostitution.
\end{abstract}

\section{Introduction}

Prostitution is theoretically the oldest line of work on the earth. The traditions in which society has observed prostitution has transformed over times gone by. The 18th century BCE Code of Hammurabi incorporated rules and regulations defending the legacy of sex workers because they usually had no male body, for example a father, older brother or husband watching out for them. In prehistoric Greece and Rome sex work was lawful and on occasions even was authorized by state. In the 590s CE, Spain had legislations grueling women who sold themselves for sexual services by thrashing them almost 300 times and enforced them into separation. During 1300-1400s in Italy, sex work was viewed as a fundamental element of life and many state-authorized brothels were in working. During early 1800s-1850s in France, a government agency known as the Bureau of Morals was formed to look over brothels to make sure that criminal activities other than prostitution were going on. In World War II, the Japanese governments snatched round about 300,000 women and girls from its terrains and taken them as sex slaves in brothels to serve up Japanese armed forces. In 1971, Nevada approved anactpermitting its counties to make a decision to criminalize sex work. Of total 17 counties, 11 legitimated or legalized sex work. In 1999, Sweden, callings work an offense not in favor of women forbidden to buy sex whereas still allowed to sell sex (Bottom et al., 2002). The practice of being engaged in immoral sexual relationship in particular for wealth is defined as prostitution(Merriam Webster Online Dictionary, 2007).

\section{Prostitution in Pakistan}

As a sovereign Muslim country, Pakistan does not formally permit prostitution. Illegally, nevertheless, the practice is widespread all over the countryside, with the greater part of the customers paradoxically composed of politicians, public servants, police officers and army staff; in brief, the very authoritative people who are believed to legislate and execute laws adjacent to the sex business. Till the late 1970s - when General Zia-ul-Haq got on upon a oblige to "Islamise" Pakistani society, shuttering down brothels to the community, red light areas as an inheritance of British rule sustained to be institutionalized. A domestic sociologist makes it clear that with the closing of brothels to the community, the sex workers whose business is quite often got through from generation to generation, detached to the cities' suburban regions to make their livelihoods. With the time passage, girls from broken and poor families also got nearer and joined them" (Ansari, 2003).

Sex work has no legal acknowledgment in Pakistan. Furthermore even though enlargement of male prostitution and gay sex work, homosexuality is forbidden in Pakistan. Under the Section 377 of the Pakistan's Penal Code, whoever 
willingly has carnal association adjacent to the order of Allah or nature with any woman, man or animal shall be beaten with 100 lashes and on or after 2 years to life imprisonment. Whereas taken into custody are not frequent for homosexuality, the act is used as a means to blackmail. Police regularly receive money or sex from persons they recognize to be indulged in profitable or non-commercial homosexual association. Pakistani law is very much prejudiced by the Penal Code introduced by the British Government in 1892. This remains a foremost part of the present Pakistani rule (West et al., 1997).

The culture, predominantly mass media is in performing a major role in regularizing sex work by representing sex work as alluring or a way to construct a lot of wealth rapidly and with no trouble (Waltman, 2011). Obviously, within the industrial world of amusement, there are many associations stuck between the movie and printing business and pornography construction, connecting tourist amusement and sex tourism. In general, the media is devoted in taking side self-development of the sex business. Within academic world, and to my great dissatisfaction, the locale of females' studies, prostitution is taught as "sex work." And prostitutes are symbolized as being authorized, self-governing, unconventional females. This is a bogus and disparaging philosophy that has marched into our courses at universities. We must be asking, about who is actually profited when prostitution is redefined as a lawful form of work for females? Do females and girls advantage? Where are these females and girls leaving to approach from? Sincesex work become lawful and standard, more and more females and girls will be required. Is this our resolution to women's poverty and being without a job? Unquestionably, it will promote the exploiters, and the country will without doubt resolve the poverty and joblessness issue for one sector of civilization. Roll them into prostitutes. Within the civilization, churches are the tone of moral authority. Unluckily, in the battle alongside prostitution, the influence of moral ability that censures all forms of sexual exploitation and cruelty is being vanished (Shaver, 2005; Scambler, 2007). Some churches are coop rationing on their assignment and their dream. In years long-ago they have been accused of being "didactic," so they have recoiled into "none disapproving" location and ways of speaking to sex work. They require-examining their retreat from this subject and reengaging in the contest. There is a significant role for churches to play in relating the damage of sex work to women, children, families, and communes. Religious communes, from the working class to the headship, require using their say of ability to combat the growing sexual abuse of sex work victims and its legalization (Hughes, 2004; Sagar, 2007).

As a minimum 25 typologies of sex work were figured out according to work place, principal form of importuning clients or sexual put into practices. These typologies of sex work are often grouped beneath the headlines of straight and roundabouts work, with the last group less probably to be professed or to make out themselves as prostitutes (Robinson et al., 2011).

There are number of evidences to prove that sex work is harmful to females directly associated, females in general, to males who purchase females in sex work to families and to civilizations; Women and children physically abused in sex work experience brutal and long lasting physical and psychological health issues, Sex Work is damaging in and of itself, i.e. the constantly frequent familiarity of submitting to unnecessary sex is very harmful to females' psychological health, self-respect and sexuality, Having to tolerate superfluous sex guides to the need to disconnect often by means of drugs and/or alcohol. Whatever the cause for female in coming sex work, her drug pills and alcohol utilization is likely to hugely boost, Many females associated in street sex work do not have concern of their children (usually as a result of drug and alcohol mistreatment). This has a well-built blow on the females themselves and is a widespread issue they require sustain on throughout services. It also has an blow on the children, the absolute family, for example grandparents rearing and bearing grandchildren, and on child fortification services, Effects on communities, most especially in localities where street sex work happens: debris, noise, boosted traffic from kerb crawlers, annoyance of local population, eye witnessing sexual movement, Only 19\% of female working as sex worker in flats, saunas and parlours are formerly from the United Kingdom (Phoenix, 2000; Poppy Project, 2003).

When brutality against females is taken, sex work is quite often excluded from the class of bigotry and inequality against females. Nevertheless, when we consider vital health impact of sex work narrates that sex work not only dangerously damages females' health condition but powerfully associates in the class of violence against females. The health expenditures or costs to females from sex work are the similar injuries and contaminations experienced by females which are faced in other types of violent behaviour against females. The physical fitness costs include the injury (bruises, wrecked down bones, black eyes and concussions). A 1994 study conducted with 68 women in Minneapolis/St.Paul who in past had been sex worked for as a minimum six months revealed that half portion of females had been bodily assaulted by their buyers, and a third of studies women practised buyers physical attack at least numerous times in a year. 23 percent of studied females were beaten ruthlessly sufficient to have experienced wrecked bones. 2 experienced brutality so cruel that they were crushed into an unconsciousness state. Moreover, 90 percent of the females in this research had practised cruelty in their private relationships ensuing in the miscarriage, wounding, loss 
of realization, and head grievances (Parriott, Health occurrences of Twin Cities' females Used in Sex Work).

The sex work is physically destructive to females in sex sharing business. Sexually transmitted diseases (as well as HIVIAIDS, Chlamydia, gonorrhoea, herpes, human being papilloma virus, and syphilis) are frighteningly high among females in sex sharing business. Only $15 \%$ of the females in the Minneapolis/St. Paul study had by no means contracted one of the Sexually transmitted diseases, not as well as AIDS, most damaging to health (Chlamydia, herpes, syphilis, gonorrhoea,). General gynaecological exertions, but in particular chronic pelvic ache and pelvic provocative sickness (PID), plague women in sex work. The Minneapolis/St. Paul research reported that $31 \%$ of the females dialogued had experienced as a minimum one episode of PID which accounts for the majority of the serious illness connected with Sexually transmitted diseases. Among these females, there was also a higher occurrence of optimistic pap spreads, several times superior than the Minnesota Department of Health's cervical cancer viewing program for little and centre profits females. More Sexually transmitted diseaseexperiences can boost the threat of cervical cancer.

\section{Materials and Methods}

Methodology is an efficient manner of studying the research that is being carried out scientifically (Nachmias and Nachmias, 1981). There are mainly two types of methods of conducting research which are generally used in the data anthology, scrutiny and explanation; these are recognized as quantitative and qualitative techniques (Ghauri et al,1995). Qualitative researcher lessons things in their original setups, trying to understand, or to interpret, phenomenon in stipulations of the meanings people fetch to them. Qualitative research is planned to go through to the deeper implication that the theme of the research is attributed to the topic on which research is being conducted. In present study, Qualitative Research method was used to find out the answers of research questions and analysis was carried out through case study method. The universe of present study was female prostitutes of District Sahiwal, Punjab. There were 5 well known Red Light areas in District Sahiwal. A sample of 10 female prostitutes was selected using purposive sampling technique for case studies. For data collection, a semi-structured interview schedule/ checklist was constructed. Human behavior is complex that cannot be treated under controlled conditions as it happens of physical sciences. It also depends upon the researcher's efforts and experience to get reliable and correct information by observing and creating atmosphere of harmony, technically called "rapport". Researcher spent 4 months in the field for the purpose of data collection. During the research work and interviewing, many difficulties were face. Many prostitutes were not agreed to give data and many were afraid of media and police but after some conversation researcher was able to convince them and collect data.

\section{Results and Discussion}

The present research was conducted to determine socio-economic and psychological causes of female prostitution in Punjab, Pakistan. Present research was also intended to figure out the social adjustment problems faced by female prostitutes, to know about the different types of violence faced by female prostitutes and to suggest some constructive measures for the mitigation of the problem. In present study number of causes and issues regarding prostitution were identified. Originally Prostitution was and is in much generalized terms, a product of society. Almost all respondents of present study were going through adverse economic conditions when they involved in prostitution. Sex sharing business is fast money giver to all its business partners. Many women found themselves in dire straits and turned to sex work as a mean of survival. Few respondents also choose sex work as their way of life; mainly when they were deprived of basic needs as well as support of male members. A vast majority of respondents had experienced early age sex so it can be one main reason of their involvement in prostitution. A very few women join sex sharing business for enjoyment and to lead glamorous lives. Women, who found themselves unaccompanied, for whatever cause, would find comfort and companionship in their fellow workers or friends and almost all study respondents were advised by their friends or present colleagues to join sex sharing business. Some females see this as a way to lead them to a new business venture which is their eventual goal in life. So in short, it can be concluded that main causes of prostitution can be financial crises or poverty, rape, sexual or physical harassment, mental illness, use of alcohol or drug addiction, watching porn and XXX movies in early age, early age sex experience, divorce, lack of education, and the list goes on. Astonishingly, maybe to you, Sex Work is quite often a big business choice but it's a survival strategy for females.

Almost all prostitutions interviewed during present study were deprived of female friends other than prostitutes. They were living their lives in social alienation and were not open heartily accepted by the usual members of the society. People witness prostitution as a field they hate the most yet demand is generated by people too. All female prostitutes were bullied by street boys and were facing social adjustment problems. 
Many studies have revealed that prostitution have adverse health impacts both on prostitutes and males who become their partner in sex. In present study, most of the female prostitutes were facing bad health consequences. Some of them had been operated and were then not able to give birth to babies.

Females have to bear uncountable discriminations living in a patriarchal society. Females are considered weak and are violated by males. In present study it was revealed that all prostitutes were harmed by their male buyers or pimps for once or more. They were usually threatened to take unnatural positions and generate sexual voices to entertain their buyers. They had to work extra hours to entertain their pimps.Sex workers do not report generally assaults to the police since they either fear revenge by pimps or consider the police will not initial the matter gravely, or will accuse them for importuning.

Prostitution is a survival strategy for females as described above, no one in present research was found satisfactory by this profession. Most of the prostitutes wanted to leave this profession if they got good job or male support. They were down and out by the bad consequences of sex sharing business.

\section{Conclusions}

After the analysis of data the researcher was able to find out the socio-economic and psychological causes and draw research conclusions on the basis of analysis. Although prostitution is illegal in Pakistan and any person found involved in selling or buying sex can be convicted by the court yet it is being done in almost all cities of Pakistan most commonly in big cities. In the light of present research it is concluded that main causes of prostitution can be financial crises or poverty, rape, sexual or physical harassment, mental illness, use of alcohol or drug addiction, watching porn and XXX movies in early age, early age sex experience, divorce, lack of education, and the list goes on. Astonishingly, maybe to you, Sex Work is quite often a big business choice but it's a survival strategy for females. Nowadays, males are no more unseen in their function of carrying on sex work and sex trafficking. An extra and all-inclusive analysis of the universal sex buy and sell has carried the "demand" face to the concentration of advocates, scholars, and government officials. The headline is if at hand refusals of demand were, sex work would not survive. "If males, the world above did not require sex, there would surely be no requirement to corral, crack and give in thousands of females and kids to this inhuman practice of prostitution.

The world on the loose has to carry on talking regarding the males those who are the main purchasers. Males are the ones who have to be answerable, to receive liability for their own conduct, and end purchasing and sexually making the most of females and girls. Governmental and non-governmental organizations (NGOs) will have to carry on talking about and acting against these customers and buyers while as well as discovering ways to help females to leave sex work. Society too requires becoming more conscious of the worth of females and girls and in which way the sexualisation of females, particularly, is a side street and growing difficulty and is damaging to females' self-worth and strong growth. It is supposed that by going to the core causes of sex work and trafficking, which are the reasons that constitute the demand, will we finish the sexual mistreatment and exploitation of women and children through sex work and trafficking?

\section{Suggestions/Recommendations}

In the light of the above conclusions, there are following steps that can help out in minimizing prostitution in Pakistan:

- Females should be given equal social, economic and political opportunities so that they can easily settle themselves in society and their dependency on males can be finished.

- Government and Civil Society organizations should target all sides of demand of prostitution. Supply is always generated to cope with demand.

- Every state in the world has laws prepared regarding trafficking, kidnap, compulsion, physical attack and sexual assault. The needs of the time however, are flourishing actions of persons and unlawful systems that traffic and sell females.

- As said by sex industry supporters, if females in prostitution are provided with condoms and amalgamation, their issues will be resolved. But study illustrates that females' desire more than condoms and amalgamation, they desire to leave sex work forever.

- All governments, NGOs, and religious communities should spotlight on plummeting the demand for sufferers of sex trafficking and sex work.

- Government should expand model policies, laws and bills, and enforcement approaches, including plus penalties, felony-level penalties, and management and hold up for victims.

- Public awareness campaigns are needed on issues such as sexual mistreatment; the age of contribution; 
approval and selection; the intrinsic violence and long term impacts of sex work.

- Preventative work with young people on the realities of sex work needs to be funded and supported by policy makers and donor agencies.

- More research is needed so that we can fully recognize the nature and degree of all forms of sex work and sexual mistreatment in Pakistan as well as the link between the wider sex business and sex work.

\section{References}

Ansari, M., (2003). Supply and demand: Karachi's 'call girls. Available at: http://greatreporter.com/mambo/content/view/78/2 (Accessed 14 August, 2012)

Bottom, H. Iris L. and Ulrich, M., (2002)."Women's History Then \& Now - Prostitution." Digital Writing and Research Lab.

Ghauri, P., K. Gronhaug and I. Kristianslund (1995), Research Methods in Business Studies, Hemel Hempstead, Prentice Hall.

Hughes, M.D. (2004). Prostitution: Causes and Solution. Female Prostitution: Proposals and Interventions). University of Rhode Island

Merriam-Webster Online Dictionary, (2007). "Should prostitution be legal"? Available at:http://prostitution.procon.org/view. answers.php?questionID=000116 (Accessed 14 August, 2012)

Phoenix, J. (2000) 'Prostitute Identities: Men, Money and Violence', British Journal of Criminology40: 37-55.

Poppy Project, (2003). What is Trafficking? Available at: http://www.womenssupportproject.co.uk/content/prostitution/205,172/ (Accessed at 20, May, 2013) release.

Robinson, Jonathan, and Yeh, E. (2011).“Transactional Sex as a Response to Risk in Western Kenya. "American Economic Journal: Applied Economics 3:35-64.

Sagar, T (2007) 'Tackling on-street sex work: anti-social behavior orders, sex workers and inclusive inter-agency initiatives', Criminology and Criminal Justice, Vol 7 (2): 153-168, Sage Publications, London

Scambler, G. (2007). Sex Work Stigma: Opportunist Migrants in London. Sociology, SAGE Journal Publication, Volume 41(6): 10791096, DOI: $10.1177 / 0038038507082316$

Shaver, F. M. (2005). Sex Work Research Methodological and Ethical Challenges. Journal of Interpersonal violence, Vol. 20 no. 3 29631

Waltman, M. (2011). Prohibiting sex purchasing and ending Trafficking: the Swedish prostitution law. Michigan Journal of International Law, Vol. 33, pp.133.

Nachmias, d. and Nachmias., 1981. ' ' Research Methods in the Social Sciences.' ' Second Edition, St. Martin' s Press. Inc New York.

West, James, D., Green and Richard., (1997). Sociological Control of Homosexuality: A Multi-Nation Comparison, Springer, ISBN 0-30645532. 
